\title{
Contamination and Ecological Risk Assessment of Heavy Metal in the Sediment of Turag River, Bangladesh: An Index Analysis Approach
}

\author{
Zoynab Banu ${ }^{1,2}$, Md. Shariful Alam Chowdhury ${ }^{3}$, Md. Delwar Hossain ${ }^{4}$, Ken'ichi Nakagami ${ }^{5}$ \\ ${ }^{1}$ Gas Transmission Company Ltd. (GTCL), Under the Ministry of Power, Energy and Mineral Resources, \\ Government of Bangladesh, Bangladesh \\ ${ }^{2}$ Department of Environmental Engineering, Bangladesh University of Engineering and Technology (BUET), Dhaka, Bangladesh \\ ${ }^{3}$ DMC of Dhaka Water Supply Sector Development Project (DWSSDP), Dhaka Water Supply and Sewerage Authority \\ (DWASA) \& World Bank Scholar, Graduate School of Policy Science, Ritsumeikan University, Kyoto, Japan \\ ${ }^{4}$ Department of Environmental Engineering, Faculty of Civil Engineering, Bangladesh University of \\ Engineering and Technology (BUET), Dhaka, Bangladesh \\ ${ }^{5}$ Graduate School of Policy Science, Ritsumeikan Center for Sustainability Science, Ritsumeikan University, Kyoto, Japan \\ Email: zoynab.sac@gamil.com, sharifcda@gmail.com,delwar@ce.buet.ac.bd,nakagami@sps.ritsumei.ac.jp
}

Received November 18, 2012; revised December 21, 2012; accepted December 31, 2012

\begin{abstract}
Encroachment, disposal of untreated domestic and industrial wastewater and dumping of solid wastes have degraded the overall quality of the river Turag, which is located in Dhaka - the Capital City of Bangladesh. The present study investigated the extent of pollution of sediments of this river and analyzed the regional variability for the concentrations of $\mathrm{Cr}, \mathrm{Pb}, \mathrm{Zn}, \mathrm{Cu}$ and $\mathrm{Cd}$ - all of concern because of their potential toxicity, using atomic absorption spectrophotometer. As per US EPA sediment quality guideline, metal concentrations ranged between $\mathrm{Cd}$ : $0.00-0.80, \mathrm{Cr}: 32.00-75.50, \mathrm{Cu}$ : 46.30 - 60.00, $\mathrm{Pb}: 28.30$ - 36.40, and $\mathrm{Zn}: 94.60-190.10 \mathrm{mg} / \mathrm{kg}$ in the Turag river sediments. $\mathrm{Cr}, \mathrm{Cu}, \mathrm{Zn}$ belongs to moderately to highly polluted, $\mathrm{Pb}$ and $\mathrm{Cd}$ belongs to not polluted for Turag river. The heavy metals contamination in the sediments were also evaluated by applying Index of geo-accumulation (Igeo), contamination factor (Cf), pollution load index (PLI) etc. Toxicity characteristics leaching procedure (TCLP) test (US EPA 1311) for sediment samples have been performed also for metals $(\mathrm{Pb}, \mathrm{Cd}, \mathrm{Cr}, \mathrm{Cu}$ and $\mathrm{Zn})$ to determine the readily toxicity level of heavy metals. Sieve analysis of sediment performed in this study to determine the physical characteristic of sediment samples. The metal concentrations are well below the regulated level as per US EPA. This index can be complemented with the contamination index, which allows more site-specific and accurate information on contaminant levels. If the aim of work on contamination evaluation is to assess the overall contamination of a study area, the indices are highly appropriate.
\end{abstract}

Keywords: Heavy Metal; TCLP Test; Sediment; Geo-Accumulation Index; Ecological Risk Index; Contamination Factor; Turag River etc.

\section{Introduction}

The River Turag running by the side of the Dhaka City, the capital of Bangladesh, is one of the most polluted rivers in Bangladesh. Many industries have set up in and around the Dhaka City during last decade, and the number of new industries are continually increasing [1]. The river Turag have been steadily experiencing complicated problems like pollution and encroachment that have almost suffocated these valuable lifelines of the city The highest pollution points of the Turag River include the Buriganga Third Bridge area at Bashila and the Tongi Bridge area. At these two points, the river water is pitchblack with the worst of smell and can be used for hardly any purpose. The other extreme pollution spot is near the Tongi Bridge that derives massive pollutant loading from the Tongi Industrial Area. This industrial area possesses about 29 heavy industries. This cluster of industries of the capital city generates a lot of effluents daily, which contain lots of heavy metal. Pollution of the natural environment by heavy metals is a universal problem because these metals are indestructible and most of them have toxic effects on living organisms, when permissible concentration levels are exceeded. Heavy metals frequently reported in literature with regards to potential hazards and occurrences in contaminated soils are $\mathrm{Cd}, \mathrm{Cr}$, $\mathrm{Pb}, \mathrm{Zn}, \mathrm{Fe}$ and $\mathrm{Cu}$ [2]. Vehicle exhausts, as well as several industrial activities emit these heavy metals so that 
soils, plants and even residents along roads with heavy traffic loads are subjected to increasing levels of contamination with heavy metals [3]. Heavy metals contamination in aquatic environment is of critical concern, due to toxicity of metals and accumulation in aquatic habitats. Trace metals in contrast to most pollutants, not biodegradable, and they undergo a global ecological cycle in which natural water are the main pathways. Of the chemical pollutants, heavy metal being non-biodegradeable, they can concentrated along the food chain, producing their toxic effect at points after far removed from the source of pollution [4]. Exposure to heavy metals has linked to several human diseases such as development retardation or malformation, Kidney damage, Cancer, abortion, effect on intelligence and behavior, and even death in some cases of exposure to very high concentration. The symptoms of toxic heavy metal poisoning and the symptoms of autism, PDD, Aspergers, \& ADD/ ADHD are very similar. Toxic metals could be the cause of those symptoms. Memory loss, increased allergic reactions, high blood pressure, depression, mood swings, irritability, poor concentration, aggressive behavior, sleep disabilities, fatigue, speech disorders, high blood pressure, cholesterol, triglycerides, vascular occlusion, neuropathy, autoimmune diseases, and chronic fatigue are just some of the many conditions resulting from exposure to toxins $[3,4]$. Heavy metals poison us by disrupting our cellular enzymes, which run on nutritional minerals such as magnesium, zinc, and selenium. The heavy metals most often implicated in human poisoning are lead, mercury, arsenic, and cadmium. Some heavy metals, such as zinc, copper, chromium, iron, and manganese, are required by the body in small amounts, but these same elements can be toxic in larger quantities. Toxic heavy metals may lead to a decline in the mental, cognitive, and physical health of the individual.

\section{Objectives}

The overall objective of the present study is to assess the heavy metal contamination in river sediments of some polluted rivers. Specific objectives of this study include:

- To assess the level of heavy metal concentrations in the sediment, its spatial distribution and compare it with the USEPA quality guideline.

- Application of advanced statistical techniques such as principal component analysis, cluster analysis and correlation matrix in order to investigate the complex dynamics of pollutants, source of heavy metal concentration in the sediments and relationships.

- To select different pollution indices to assess heavy metal contamination.

- To assess the ecological risk due to sediment contamination.

\section{Method and Materials}

Sediments sample were collected from five sites along the Turag River as showing in Figure 1, Latitude and Longitude for each site were illustrated in Table 1. The sediment samples were directly collected from the Turag River during the dredging of Turag bed sludge. The samples were carried by polythene bag. After collection, some portion of sediment samples were dried in a vacuum oven at $105^{\circ} \mathrm{C}$ until constant weight, lightly ground in an agate mortar for homogenization and prepared for analysis of heavy metal and some portion of samples were prepared for sieve analysis, moisture content and organic content test. For heavy metal test, $5 \mathrm{gm}$ of dried sample was digested with acid and prepared $500 \mathrm{ml}$ solution. Finally, five heavy metals $(\mathrm{Pb}, \mathrm{Cd}, \mathrm{Cr}, \mathrm{Cu}$, and $\mathrm{Zn})$ concentration were determined in the environmental engineering laboratory, BUET by using atomic absorption spectrophotometer (AAS). To determine the physical characteristics of sediment, moisture content, organic matter content and sieve analysis test were also performed. Toxicity characteristics leaching procedure (TCLP) test for sediment samples were performed for five heavy metals $(\mathrm{Pb}, \mathrm{Cd}, \mathrm{Cr}, \mathrm{Cu}$ and $\mathrm{Zn})$ to determined the readily toxicity level of heavy metals. Heavy metal concentration for the fine portion of sediment samples (sample which passing through \# 200 sieve) were also performed in this study.

The selected sample drawing points of the Turag River includes the points near Iztema Field, Tongi Bridge, Gabtali Bridge and Sinnir Tek BIWTA Landing Station. Analyzing the DoE provided water quality data of 5 years (2006-2010) (Table 2), the following temporal pattern of the Turag River Pollution has been found (Figure 2).

Due to rapid and unplanned urbanization and industrialization the Dhaka city's surrounding rivers, including the Turag have gradually experienced undue and unbearable pressure to their very existence. The main reason behind this spatial pollution pattern in the Turag within above mentioned area is that huge load of untreated toxic liquid chemical waste is directly dumped into the river from Hazaribagh tanneries through the Bashila Khal at the downstream and from the Tongi Industrial Area at

Table 1. Location of sediment sample collection.

\begin{tabular}{cccc}
\hline Station No. & Name of Location & Longitude & Latitute \\
\hline 1 & Tongi Bridge & $90^{\circ} 24^{\prime} 4.04^{\prime \prime} \mathrm{E}$ & $23^{\circ} 52^{\prime} 54.30^{\prime \prime} \mathrm{N}$ \\
2 & World Estema Field & $90^{\circ} 23^{\prime} 37.98^{\prime \prime} \mathrm{E}$ & $23^{\circ} 52^{\prime} 47.64^{\prime \prime} \mathrm{N}$ \\
3 & Kamarpara Bridge & $90^{\circ} 23^{\prime} 23.61^{\prime \prime} \mathrm{E}$ & $23^{\circ} 53^{\prime} 27.88^{\prime \prime} \mathrm{N}$ \\
4 & Taltola Bridge & $90^{\circ} 22^{\prime} 40.97^{\prime \prime} \mathrm{E}$ & $23^{\circ} 53^{\prime} 54.98^{\prime \prime} \mathrm{N}$ \\
5 & Ashulia Beri Bandh & $90^{\circ} 21^{\prime} 37.41^{\prime \prime} \mathrm{E}$ & $23^{\circ} 53^{\prime} 33.34^{\prime \prime} \mathrm{N}$ \\
\hline
\end{tabular}




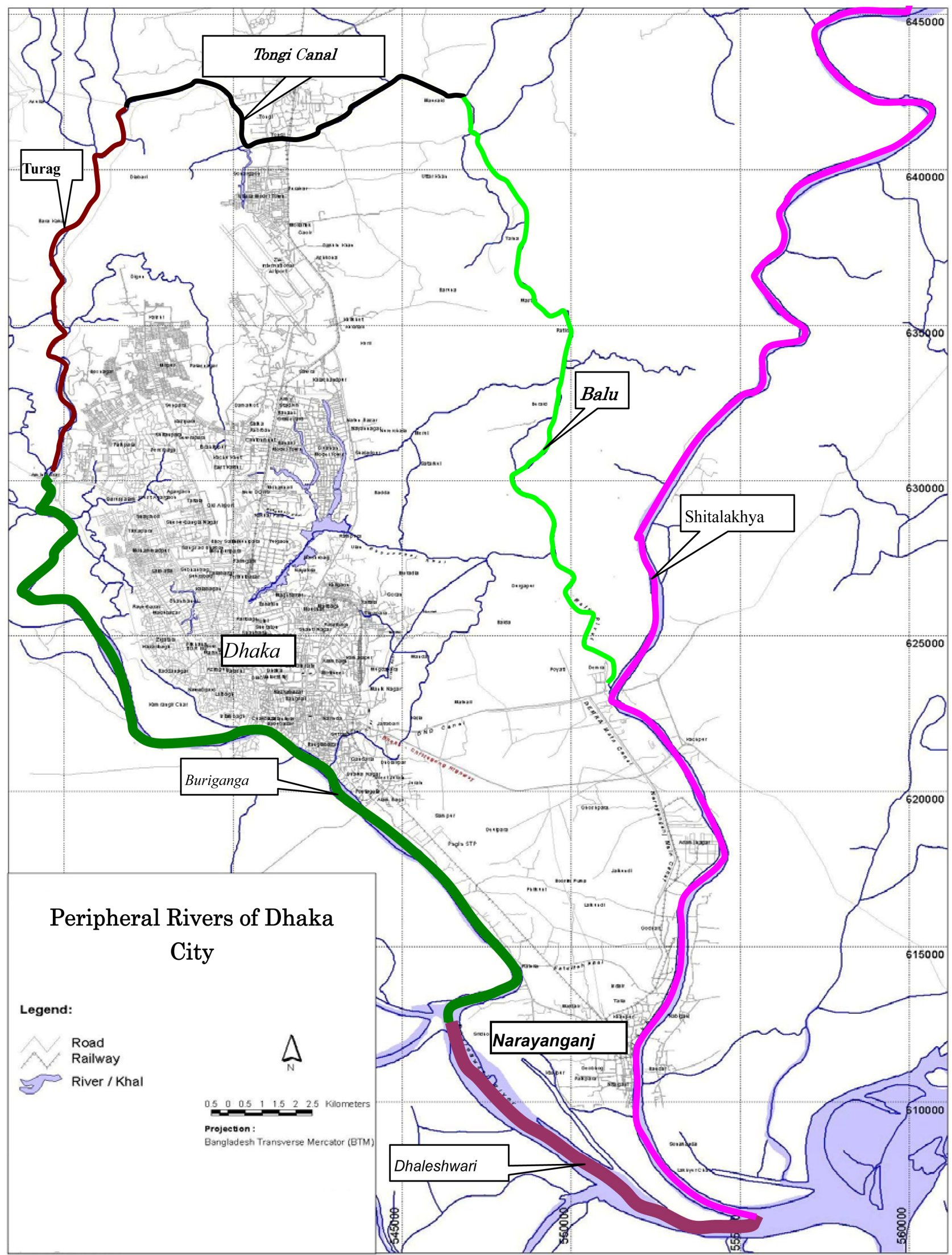

Figure 1. Map of peripheral rivers around Dhaka city. 


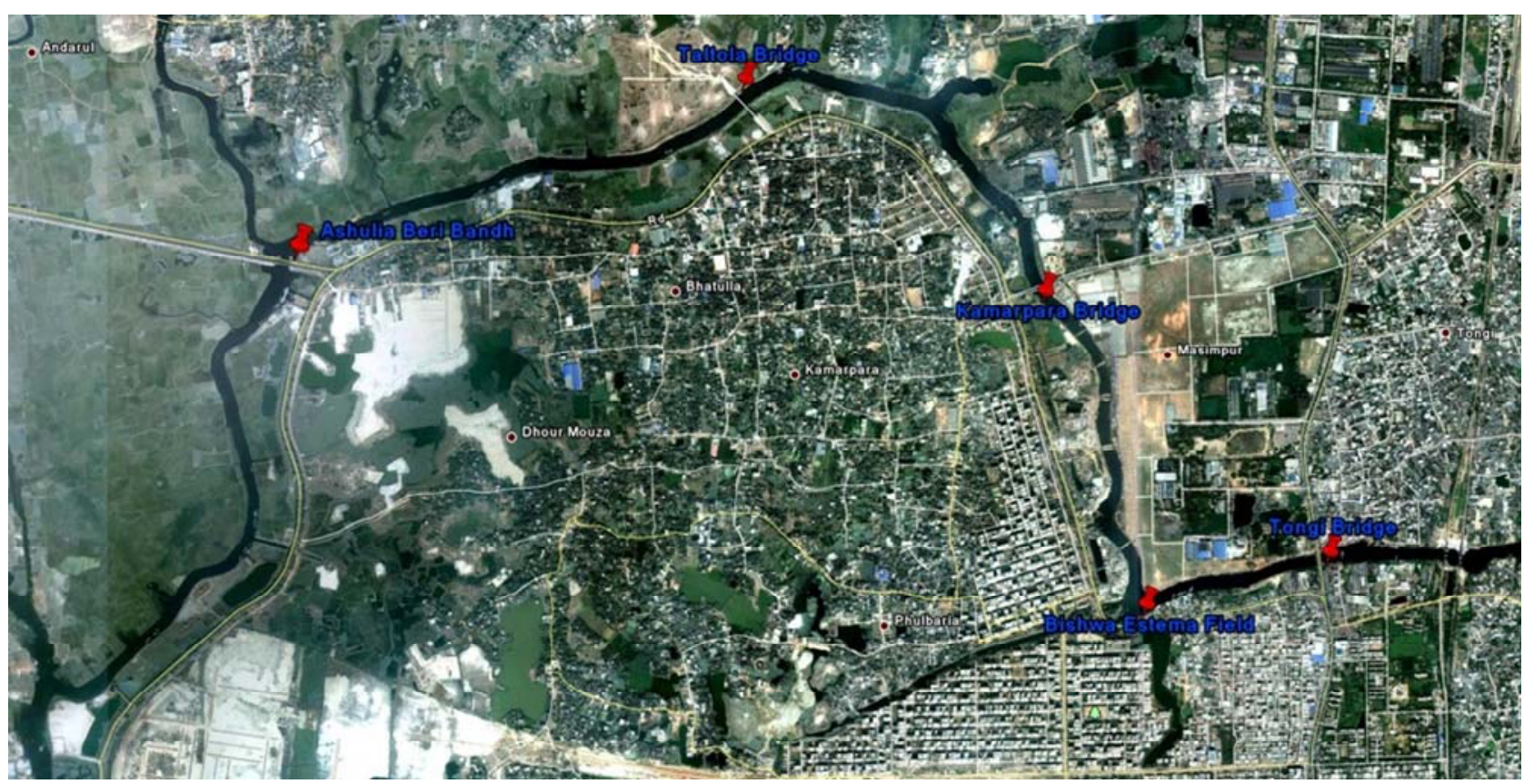

Figure 2. Location of coordinates of different sites in Turag river.

Table 2. Variation of water quality parameters in Turag river during 2006-2010 [5].

\begin{tabular}{cccc}
\hline Parameter & Unit & 2006 & 2010 \\
\hline $\mathrm{pH}$ & $\mathrm{mg} / \mathrm{L}$ & 7.1 & 7.5 \\
EC &, & 98 & 1800 \\
Chloride &, & 2 & 34 \\
Turbidity &, & 6.5 & 12.5 \\
TS &, & 380 & 896 \\
TDS &, & 342 & 812 \\
DO &, & 6 & 0 \\
BOD &, & 2.8 & 22 \\
COD &, & 58 & 102 \\
\hline
\end{tabular}

Tongi Bridge and Iztema Field area.

\section{Result and Discussion}

\subsection{Heavy Metal Concentrations}

The total metal concentrations for each sampling site found in sediments in this study are shown in Table 3. Metal contents were ranging over following intervals: $\mathrm{Pb}$ : $28.30-36.40 \mathrm{mg} / \mathrm{kg}$; Cd: $0.0-0.80 \mathrm{mg} / \mathrm{kg}$; Cr: 32.0 $75.50 \mathrm{mg} / \mathrm{kg}$; Cu: 46.30 - $60.0 \mathrm{mg} / \mathrm{kg}$; Zn: 94.60 - 190.10 $\mathrm{mg} / \mathrm{kg}$ dry weights. Mean concentration of the metals were: $\mathrm{Pb}: 32.78 \mathrm{mg} / \mathrm{kg}$; Cd: $0.28 \mathrm{mg} / \mathrm{kg}$; Cr: $43.02 \mathrm{mg} / \mathrm{kg}$; $\mathrm{Cu}: 50.40 \mathrm{mg} / \mathrm{kg}$; Zn: $139.48 \mathrm{mg} / \mathrm{kg}$ dry weights, allowing to arrange the metals from higher to lower mean
Table 3. Concentration of heavy metals (mg/kg dry weight) of sediments of Turag river.

\begin{tabular}{cccccc}
\hline Location & Lead $(\mathrm{Pb})$ & $\begin{array}{c}\text { Cadmium } \\
(\mathrm{Cd})\end{array}$ & $\begin{array}{c}\text { Chromium } \\
(\mathrm{Cr})\end{array}$ & $\begin{array}{c}\text { Copper } \\
(\mathrm{Cu})\end{array}$ & Zinc $(\mathrm{Zn})$ \\
\hline T-1 & 36.40 & 0.10 & 36.00 & 60.00 & 179.30 \\
$\mathrm{~T}-2$ & 34.40 & 0.10 & 33.50 & 46.30 & 113.80 \\
$\mathrm{~T}-3$ & 30.40 & 0.00 & 75.50 & 46.40 & 190.10 \\
T-4 & 28.30 & 0.40 & 32.00 & 50.00 & 94.60 \\
T-5 & 34.40 & 0.80 & 38.10 & 49.30 & 119.60 \\
Mean & 32.78 & 0.28 & 43.02 & 50.40 & 139.48 \\
Max & 36.40 & 0.80 & 75.50 & 60.00 & 190.10 \\
Min & 28.30 & 0.00 & 32.00 & 46.30 & 94.60 \\
SD & 3.32 & 0.33 & 18.31 & 5.62 & 42.48 \\
\hline
\end{tabular}

content in this area as: $\mathrm{Zn}>\mathrm{Cu}>\mathrm{Cr}>\mathrm{Pb}>\mathrm{Cd}$.

Pearson's correlation coefficient matrix among the selected heavy metals of Turag river sediments is presented in Table 4. Significant correlations between the contaminants of $\mathrm{Cr}$ and $\mathrm{Zn}(\mathrm{r}=0.71), \mathrm{Pb}$ and $\mathrm{Cu}(\mathrm{r}=0.50)$, $\mathrm{Zn}$ and $\mathrm{Cu}(\mathrm{r}=0.34)$ could indicate the same or similar source input.

\subsection{Physical Characteristic of Sediment (Sieve Analysis)}

Sieve analysis result of sediment sample is presented in the Table 5. Average in all sites, $1.75 \%$ materials retain on \#4 and above sieve and $25.34 \%$ materials passing 
Table 4. Correlation matrix between heavy metals in sediment samples from Turag river.

\begin{tabular}{cccccc}
\hline & $\mathrm{Pb}$ & $\mathrm{Cd}$ & $\mathrm{Cr}$ & $\mathrm{Cu}$ & $\mathrm{Zn}$ \\
\hline $\mathrm{Pb}$ & 1 & & & & \\
$\mathrm{Cd}$ & 0.01 & 1 & & & \\
$\mathrm{Cr}$ & -0.32 & -0.42 & 1 & 1 & \\
$\mathrm{Cu}$ & 0.50 & -0.07 & -0.36 & 0.34 & 1 \\
$\mathrm{Zn}$ & 0.27 & -0.58 & 0.71 & \\
\hline
\end{tabular}

Table 5. Sieve analysis result of the sediment sample of the Turag river.

\begin{tabular}{cccccc}
\hline \multirow{2}{*}{$\begin{array}{c}\text { Sieve Size } \\
\text { (ASTM) }\end{array}$} & Station 1 & Station 2 & Station 3 & Station 4 & Station 5 \\
\cline { 2 - 5 } & \% Materials & \% Materials & \% Materials & \% Materials & \% Materials \\
\cline { 2 - 5 } Netains (gms) & Retains (gms) & Retains (gms) & Retains (gms) & Retains (gms) \\
\hline No. 16 & 4.12 & 7.33 & 4.89 & 0.70 & 2.52 \\
No. 30 & 4.31 & 12.20 & 6.82 & 7.61 & 6.59 \\
No. 200 & 6.83 & 11.43 & 7.07 & 12.48 & 8.77 \\
PAN & 53.32 & 40.30 & 50.01 & 44.37 & 49.51 \\
TOTAL & 10.72 & 29.42 & 30.58 & 33.64 & 31.86 \\
\% Coarse & 100.0 & 100.0 & 100.0 & 100.0 & 100.0 \\
\% Medium & 6.43 & 19.53 & 11.71 & 8.31 & 9.11 \\
\% Fine & 30.85 & 51.05 & 57.71 & 58.05 & 59.03 \\
\hline
\end{tabular}

through the \#200 sieve whereas $72.90 \%$ materials retain on \#8 to \#200 sieves that indicate the sediment size of the Buriganga River ranges over medium to fine size and it contains a significant amount of fine particle. The average moisture content and organic matter content of the sediment sample are $82.26 \%$ and $7.12 \%$ respectively. A relationship is found between the moisture content and organic matter content. Higher moisture content in the sediment sample shows the higher organic matter content. There is another relationship found in this study, the sites which contain higher organic matter shows higher heavy metal concentration. For example, Station No. 4 and 5 which contain higher organic matter $(10.14 \%$ and $12.2 \%$ respectively) showed higher heavy metal content (Figures 3-6 are the most sediment contamination scenario of Turag river, Dhaka).

\section{Assessment of Heavy Metal Contamination}

\subsection{Assessment According to United States Environmental Protection Agency (USEPA)}

Protection Agency (USEPA) The chemical contaminations in the sediments were evaluated by comparison with the sediment quality guideline proposed by USEPA. These criteria are shown in Table 6. Present study shows that all the sites are not polluted for $\mathrm{Pb}$, Moderately Polluted for $\mathrm{Cu}, \mathrm{Cr}$ and $\mathrm{Zn}$ while for $\mathrm{Cr}$, sites 3 is Highly polluted. For $\mathrm{Cd}$, all the sites are ranges over not polluted to moderately polluted condition.

\subsection{Assessment According to Geo-Accumulation Index (Igeo)}

A common criterion to evaluate the heavy metal pollution in sediments is the geo-accumulation index. Geoaccumulation index proposed by Muller [6] to determine metals contamination in sediments, by comparing current concentrations with pre-industrial levels and can be calculated using the following formula:

$$
\mathrm{I}_{\mathrm{geo}}=\log _{2}\left[\frac{\mathrm{C}_{\mathrm{n}}}{1.5 \mathrm{~B}_{\mathrm{n}}}\right]
$$

where, $C_{n}$ is the concentration of element " $n$ " and $B_{n}$ is the geochemical background value [In this study, consider $\mathrm{B}_{\mathrm{n}}=$ world surface rock average given by Martin and Meybeck [7]]. The factor 1.5 is incorporated in the relationship to account for possible variation in back- 


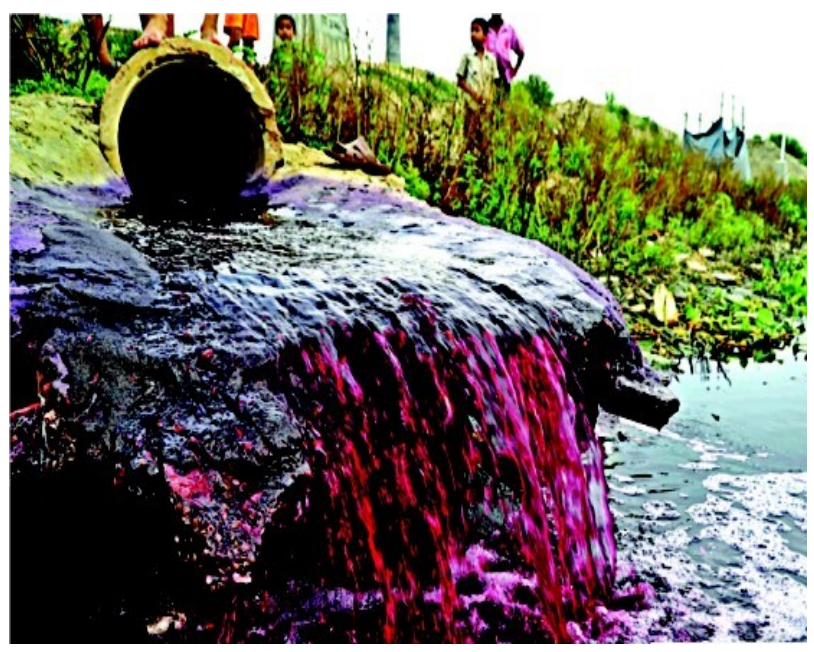

Figure 3. Textile wastewater discharge in Turag river.

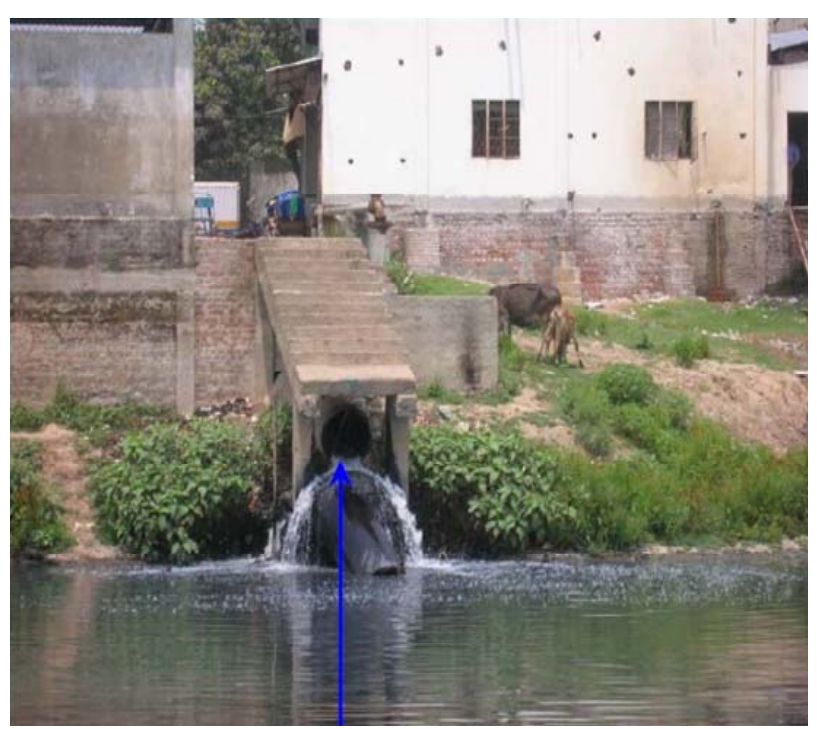

Figure 4. Industrial wastewater discharge in Turag river.

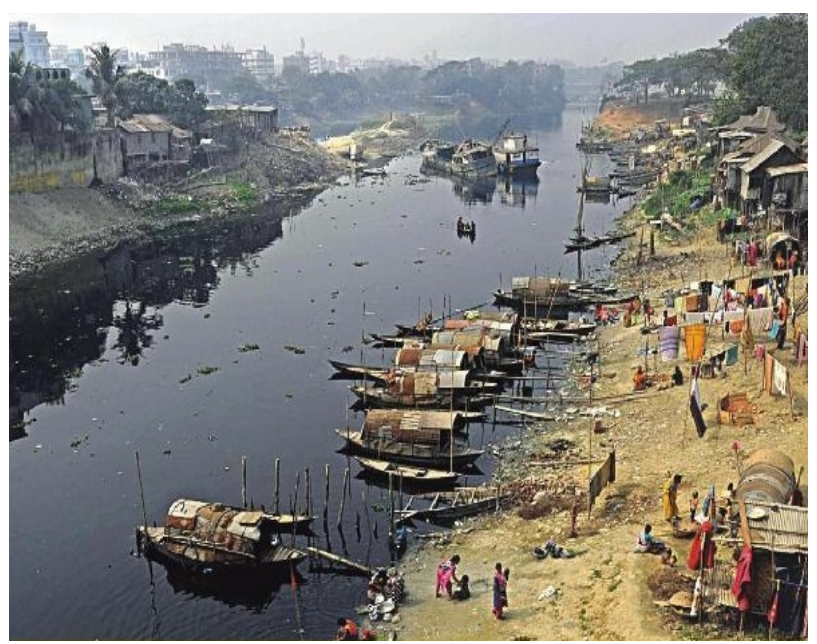

Figure 5. Pitch black water of Turag river, the west of Tongi Bridge, Dhaka, Bangladesh.

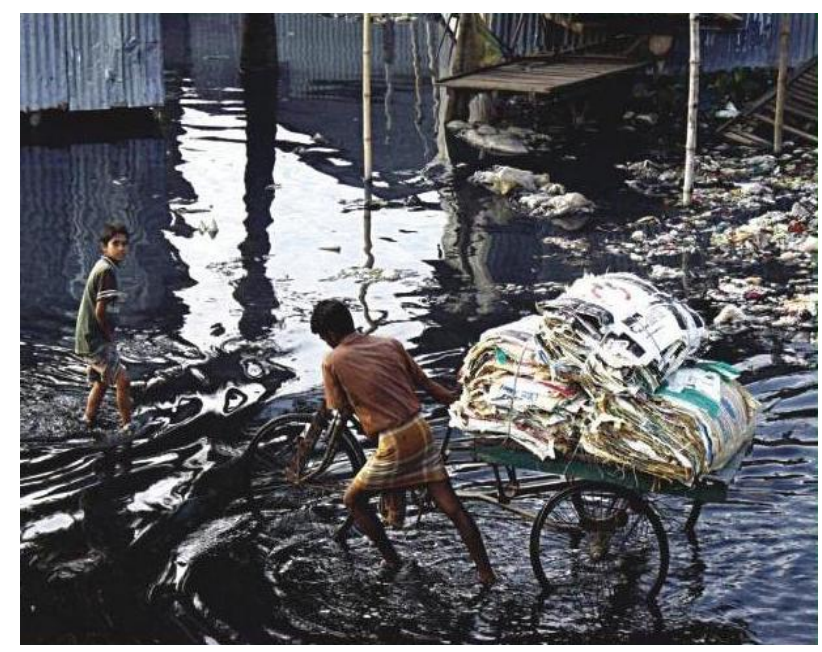

Figure 6. Pitch black water discharges from textile dyeing units in low deep canal that link with Turag river.

Table 6. USEPA Guidelines for Sediments (Mg/Kg dry weights).

\begin{tabular}{ccccc}
\hline Metal & Not polluted & $\begin{array}{c}\text { Moderately } \\
\text { polluted }\end{array}$ & $\begin{array}{c}\text { Heavily } \\
\text { polluted }\end{array}$ & Present study \\
\hline $\mathrm{Pb}$ & $<40$ & $40-60$ & $>60$ & 28.30 \\
$\mathrm{Cd}$ & $\ldots$ & $\ldots$ & $>6$ & 0.00 \\
$\mathrm{Cr}$ & $<25$ & $25-75$ & $>75$ & 32.00 \\
$\mathrm{Cu}$ & $<25$ & $25-50$ & $>50$ & 46.30 \\
$\mathrm{Zn}$ & $<90$ & $90-200$ & $>200$ & 94.60 \\
\hline
\end{tabular}

ground data due to lithogenic effect. The geo-accumulation index (Igeo) scale consists of seven grades $(0-6)$ ranging from unpolluted to highly pollute (shown in Table 7). According to the Muller scale, the calculated results of $\mathrm{I}_{\text {geo }}$ values shown in Table 8.

\subsection{Assessment According to Contamination Factor}

The contamination factor and degree of contamination are used to determine the contamination status of the sediment in the present study. Contamination factor is calculated according to D. C. Thomilson, D. J. Wilson, C. R. Harris, D. W. Jeffrey [4].

$$
\mathrm{CF}=\frac{\mathrm{C}_{\text {metal }}}{\mathrm{C}_{\text {background }}}
$$

In this study world surface rock average proposed by Martin and Meybeck [7] is considered as background concentration.

$\mathrm{CF}<1$ : low contamination factor; $1 \leq \mathrm{CF}<3$ : moderate contamination factor; $3=\mathrm{CF}<6$ : considerable contamination factor; $\mathrm{CF}=6$ : very high contamination factor. 
Table 7. MULLER'S classification for the geo-accumulation.

\begin{tabular}{ccc}
\hline Igeo Value & Class & Sediment Quality \\
\hline$\leq 0$ & 0 & Unpolluted \\
$0-1$ & 1 & From unpolluted to moderately polluted \\
$1-2$ & 2 & Moderately polluted \\
$2-3$ & 3 & From moderately to strongly polluted \\
$3-4$ & 4 & Strongly polluted \\
$4-5$ & 5 & From strongly to extremely polluted \\
$>6$ & 6 & Extremely polluted \\
\hline
\end{tabular}

Table 8. Geo-accumulation index $\left(\mathrm{I}_{\text {geo }}\right)$ at different sampling station in Turag river by Muller (1979).

\begin{tabular}{cccccc}
\hline Location & $\mathrm{Pb}$ & $\mathrm{Cd}$ & $\mathrm{Cr}$ & $\mathrm{Cu}$ & $\mathrm{Zn}$ \\
\hline $\mathrm{T}-1$ & 0.28 & -1.58 & -2.01 & 0.32 & -0.11 \\
$\mathrm{~T}-2$ & 0.20 & -1.58 & -2.12 & -0.05 & -0.77 \\
$\mathrm{~T}-3$ & 0.02 & - & -0.95 & -0.05 & -0.03 \\
$\mathrm{~T}-4$ & -0.08 & 0.42 & -2.18 & 0.06 & -1.03 \\
$\mathrm{~T}-5$ & 0.20 & 1.42 & -1.93 & 0.04 & -0.69 \\
\hline
\end{tabular}

$$
\mathrm{PLI}=\left(\mathrm{CF}_{1} \times \mathrm{CF}_{2} \times \mathrm{CF}_{3} \times \cdots \times \mathrm{CF}_{\mathrm{n}}\right)^{(1 / \mathrm{n})}
$$

If PLI $<1$ indicates no pollution. PLI $>1$ indicates polluted sediment.

The degree of contamination (Cd) is defined as the sum of all contamination factors (see Table $\mathbf{9}$ ).

The deteriorating condition of the Turag/Buriganga River in the mid-1990s stimulated the pollution Hotspots of Dhaka (see Figure 7). Most of the effort focused on public awareness, processions, monitoring of the Dhaka canal and river system, and destruction of buildings that encroached on the Turag River [5].

Table 10 shows contamination factor, pollution load index and degree of contamination at different locations along Turag river. All locations are moderately contaminated with lead. T-1, T-2 and T-3 are less contaminated, $\mathrm{T}-4$ moderately contaminated and T-5 considerably contaminated with cadmium. All locations have low contamination due to chromium and moderate contamination for copper. T-1 and T-3 are moderately contaminated; $\mathrm{T}-2, \mathrm{~T}-4$ and $\mathrm{T}-5$ are less contaminated with zinc. As per pollution load index, T-4 and T-5 locations sediment are polluted and T-1, T-2 and T-3 are not polluted. Highest pollution load index value is observed at T-5 and minimum at T-3. Degree of contamination values range from 4.89 to 8.58. Maximum value of degree of contamination was found at T-5 and minimum at T-2. As per degree of contamination it is found that T-4 and T-5 are the loca-
Table 9. Terminologies used to describe the contamination factor.

\begin{tabular}{ccc}
\hline $\mathrm{CF}$ & $\mathrm{C}_{\mathrm{d}}$ & Description \\
\hline $\mathrm{CF}<1$ & $\mathrm{C}_{\mathrm{d}}<6$ & Low degree of contamination \\
$1<\mathrm{CF}<3$ & $6 \leq \mathrm{C}_{\mathrm{d}}<12$ & Moderate degree of contamination \\
$3<\mathrm{CF}<6$ & $12 \leq \mathrm{C}_{\mathrm{d}}<24$ & Considerable degree of contamination \\
$\mathrm{CF}>6$ & $\mathrm{C}_{\mathrm{d}} \geq 24$ & Very high degree of contamination \\
\hline
\end{tabular}

tions of moderate contamination and T-1, T-2 and T-3 are the locations of low contamination.

\subsection{Assessment According to Pollution Load Index (PLI): Ecological Risk Index}

For each contaminant the PLI is calculated using the formula proposed by Wilson and Jeffrey [8]:

$$
\mathrm{PLI}=\text { anti } \log _{10}\left(1-\frac{\mathrm{C}-\mathrm{B}}{\mathrm{T}-\mathrm{B}}\right)
$$

$\mathrm{B}$ is the baseline value - not contaminated; $\mathrm{T}$ the threshold, minimum concentrations associated with degradation or changes in the quality of the estuarine system. Wilson and Jeffrey [8] define $\mathrm{B}$ and $\mathrm{T}$ for the different contaminants; $\mathrm{C}$ the concentration of the pollutant. For each place the PLI calculation takes into account all the $n$ contaminants:

$$
\mathrm{PLI}=\left(\mathrm{PLI}_{1} \times \mathrm{PLI}_{2} \times \mathrm{PLI}_{3} \times \cdots \times \mathrm{PLI}_{\mathrm{n}}\right)^{(1 / \mathrm{n})}
$$

PLI varies from 10 (unpolluted) to 0 (highly polluted).

This index allows the comparison between several estuarine systems. It has been applied successfully in European estuaries.

Values of baseline and threshold not defined locally for each coastal zone analyzed and not recently revised.

Pollution load index at different locations of Turag river is shown in Table 11. For Turag river, all locations are moderately polluted as per pollution load index proposed by Wilson and Jeffrey [8].

\subsection{Assessment According to Potential Ecological Risk Index}

In 1980, Lars Hakanson reported an ecological risk index for aquatic pollution control; therefore, Hakanson's method has been often used in ecological risk assessment as a diagnostic tool to penetrate one of many possible avenues towards a potential ecological risk index, i.e., to sort out which drainage area, reservoir, and substances should be given special attention [9].

The index is calculated as the following equations:

$$
C_{f}^{i}=\frac{C_{D}^{i}}{C_{R}^{i}}
$$


Table 10. Pollution load index and degree of contamination of Turag river sediments.

\begin{tabular}{|c|c|c|c|c|c|c|c|c|c|}
\hline \multirow{3}{*}{$\begin{array}{c}\begin{array}{c}\text { Sample } \\
\text { Location }\end{array} \\
\mathrm{T}-1\end{array}$} & \multicolumn{5}{|c|}{ Contamination factor of single metal } & \multirow{2}{*}{\multicolumn{2}{|c|}{ PLI }} & \multirow{2}{*}{\multicolumn{2}{|c|}{$\begin{array}{c}\text { Degree of contamination } \\
\text { by Tomlinson et al. (1980) }\end{array}$}} \\
\hline & \multirow{2}{*}{$\frac{\mathrm{Pb}}{1.82}$} & \multirow{2}{*}{$\frac{\mathrm{Cd}}{0.50}$} & \multirow{2}{*}{$\frac{\mathrm{Cr}}{0.37}$} & \multirow{2}{*}{$\frac{\mathrm{Cu}}{1.88}$} & \multirow{2}{*}{$\frac{\mathrm{Zn}}{1.39}$} & & & & \\
\hline & & & & & & 0.97 & Unpolluted & 5.96 & Low \\
\hline $\mathrm{T}-2$ & 1.72 & 0.50 & 0.35 & 1.45 & 0.88 & 0.82 & Unpolluted & 4.89 & Low \\
\hline $\mathrm{T}-3$ & 1.52 & 0.00 & 0.78 & 1.45 & 1.47 & 0.00 & Unpolluted & 5.22 & Low \\
\hline $\mathrm{T}-4$ & 1.42 & 2.00 & 0.33 & 1.56 & 0.73 & 1.01 & Polluted & 6.04 & Moderate \\
\hline $\mathrm{T}-5$ & 1.72 & 4.00 & 0.39 & 1.54 & 0.93 & 1.31 & Polluted & 8.58 & Moderate \\
\hline
\end{tabular}

Table 11. Pollution load index for Turag river.

\begin{tabular}{|c|c|c|c|c|c|c|c|}
\hline \multirow{3}{*}{$\begin{array}{l}\text { Location } \\
\qquad \mathrm{T}-1\end{array}$} & \multicolumn{5}{|c|}{ Pollution load index of single metal } & \multirow{2}{*}{\multicolumn{2}{|c|}{$\begin{array}{l}\text { Combined PLI by Wilson } \\
\text { and Jeffrey (1987) }\end{array}$}} \\
\hline & \multirow{2}{*}{$\begin{array}{c}\mathrm{Pb} \\
5.13\end{array}$} & \multirow{2}{*}{$\begin{array}{c}\mathrm{Cd} \\
25.12\end{array}$} & \multirow{2}{*}{$\frac{\mathrm{Cr}}{2.04}$} & \multirow{2}{*}{$\frac{\mathrm{Cu}}{0.60}$} & \multirow{2}{*}{$\frac{\mathrm{Zn}}{0.10}$} & & \\
\hline & & & & & & 1.74 & Polluted \\
\hline $\mathrm{T}-2$ & 5.37 & 25.12 & 2.34 & 1.21 & 0.67 & 3.03 & Polluted \\
\hline $\mathrm{T}-3$ & 5.89 & 31.62 & 0.27 & 1.20 & 0.07 & 1.35 & Polluted \\
\hline $\mathrm{T}-4$ & 6.31 & 12.59 & 2.51 & 1.00 & 1.17 & 2.98 & Polluted \\
\hline T-5 & 5.37 & 5.01 & 1.84 & 1.04 & 0.57 & 1.97 & Polluted \\
\hline
\end{tabular}

$$
\begin{aligned}
C_{H} & =\sum_{i=1}^{m} C_{f}^{i} \\
E_{f}^{i} & =T_{f}^{i} \times C_{f}^{i} \\
\mathrm{RI} & =\sum_{i=1}^{m} E_{f}^{i} \\
E_{f}^{i} & =T_{f}^{i} \times C_{f}^{i}
\end{aligned}
$$

From the Table 12, in which, $C_{f}^{i}$ is the pollution coefficient of single metal; $C_{D}^{i}$ is the measured concentration of sample; $C_{R}^{i}$ is the background concentration of sediments; $C_{H}$ is the polluted coefficient of many metals; $E_{f}^{i}$ is the potential ecological risk factor of single metal; $T_{f}^{l}$ is the biological toxicity factor of different metals; and RI is the potential ecological risk index of many metals.

From Table 13, it can be seen that the order of potential ecological risk factor of heavy metals in sediments of the Turag river is $\mathrm{Cd}>\mathrm{Cu}>\mathrm{Pb}>\mathrm{Zn}>\mathrm{Cr}$; $\mathrm{Cd}$ is the most important one and its risk factor is upto the appreciable grade. The results indicate that the range of $\mathrm{Cd}$ pollution in the Turag river is low to appreciable. Other heavy metals $(\mathrm{Zn}, \mathrm{Cr}, \mathrm{Cu}$ and $\mathrm{Cu}$ ) have low potential ecological risk. The index range of potential ecological risk is from 17.88 to 138.02 , and the average index of potential ecological risk factors (RI) is 60.04. Turag river has a low to moderate potential ecological risk due to heavy metal contamination [5].
Table 12. Evaluated parameters for ecological risk index calculation.

\begin{tabular}{cccccc}
\hline Parameter & $\mathrm{Cd}$ & $\mathrm{Cr}$ & $\mathrm{Cu}$ & $\mathrm{Pb}$ & $\mathrm{Zn}$ \\
\hline $\begin{array}{l}\text { Pre-industrial background values } \\
\text { (Martin and Meybeck, 1979), } C_{R}^{i}\end{array}$ & 0.2 & 97 & 32 & 20 & 129 \\
\begin{tabular}{c} 
Toxic Response Factor, $T_{f}^{i}$ \\
\hline
\end{tabular} & 30 & 2 & 5 & 5 & 1 \\
\hline
\end{tabular}

\subsection{Assessment According to Integrated Pollution Index (PIN Index)}

A new pollution index, PIN index (a background enrichment index), was adapted from PI, and based on the Portuguese legislation on the classification of dredged materials:

$$
\mathrm{PIN}=\frac{\sum_{i=1}^{m} W_{i}^{2} C_{i}}{B_{1 i}}
$$

where $W_{i}$ is the class of the contaminant $i$ considering the degree of contamination (from 1 to $\mathrm{n}=5$ ); $C_{i}$ the concentration of the contaminant $\mathrm{i} ; B_{1 i}$ the concentration of contaminant $i$ in Class 1 (baseline value_clean sediments).

According to the legislation mentioned above, the sediments (and the index) can be classified into five categories (Table 14), from clean to highly contaminated sediments. PIN index values were normalized in a nominal scale from 1 to 5 , according to the threshold classification values. Each index threshold was calculated using 
the $W_{i}$ and $C_{i}$ values for the corresponding class

Class 1 (clean): [0 - 7];

Class 2 (trace contaminated): [7 - 95.1];

Class 3 (lightly contaminated): [95.1 - 518.1];

Class 4 (contaminated): [518.1 - 2548.6];

Class 5 (highly contaminated): [2548.6 - $\infty$ ].

PIN Index at different sampling locations along Turag river is shown in Table 15. According to PIN Index, T-1, $\mathrm{T}-3$ and $\mathrm{T}-5$ sediments are in trace contaminated condition while and T-2 and T-4 are clean condition.

\subsection{Assessment According to Toxicity Characteristics}

Leaching Procedure (TCLP) Toxicity Characteristics Leaching Procedure (TCLP) is a very important tool for assessing readily contaminated heavy metal for sediment samples [10]. In this study, heavy metal concentrations from leachate of Turag River Sediments were tested in the laboratory and pollution levels of leachate were assessed with comparison of EPA standard. Results of the TCLP test are presented in the Table 16. For all the sites, concentrations of heavy metal in leachate are not exceeded the permissible EPA standard. That indicate regarding the readily toxicity pollution by heavy metal, Turag River Sediment condition is not the severe state.

\section{Conclusion}

Geo-accumulation index, contamination factor and degree of contamination, Metal pollution index, Enrichment factor and Multivariate statistical analysis were successfully applied for the assessment of heavy metal contamination of Turag river sediments. The sediment size of the Turag river ranges over medium to fine and it also contains a significant amount of fine particles. Metal concentrations ranged between $\mathrm{Cd}: 0.00-0.80, \mathrm{Cr}: 32.00$ - 75.50, Cu: 46.30 - 60.00, Pb: 28.30 - 36.40, and $\mathrm{Zn}$ :

Table 13. Ecological risk index for Turag river.

\begin{tabular}{|c|c|c|c|c|c|c|c|}
\hline \multirow{2}{*}{ Location } & $\mathrm{Zn}$ & $\mathrm{Cd}$ & $\mathrm{Cr}$ & $\mathrm{Cu}$ & $\mathrm{Pb}$ & \multirow{2}{*}{ RI } & \multirow{2}{*}{$\begin{array}{c}\text { Grade Hakanson } \\
\text { (1980) }\end{array}$} \\
\hline & $C_{f}^{i} \times T_{f}^{i}$ & $C_{f}^{i} \times T_{f}^{i}$ & $C_{f}^{i} \times T_{f}^{i}$ & $C_{f}^{i} \times T_{f}^{i}$ & $C_{f}^{i} \times T_{f}^{i}$ & & \\
\hline $\mathrm{T}-1$ & 1.39 & 15.00 & 0.74 & 9.38 & 9.10 & 35.61 & Low \\
\hline $\mathrm{T}-2$ & 0.88 & 15.00 & 0.69 & 7.23 & 8.60 & 32.41 & Low \\
\hline $\mathrm{T}-3$ & 1.47 & 0.00 & 1.56 & 7.25 & 7.60 & 17.88 & Low \\
\hline $\mathrm{T}-4$ & 0.73 & 60.00 & 0.66 & 7.81 & 7.08 & 76.28 & Low \\
\hline $\mathrm{T}-5$ & 0.93 & 120.00 & 0.79 & 7.70 & 8.60 & 138.02 & Moderate \\
\hline
\end{tabular}

Table 14. Classification of dredge material in coastal zones according to DR, 1995.

\begin{tabular}{|c|c|c|c|c|c|c|c|}
\hline Classes/contaminants $(\mathrm{mg} / \mathrm{kg})$ & $\mathrm{Cd}$ & $\mathrm{Pb}$ & $\mathrm{Zn}$ & $\mathrm{Cu}$ & As & $\mathrm{Cr}$ & $\mathrm{Hg}$ \\
\hline Class 1: Clean dredged material & $<1$ & $<50$ & $<100$ & $<35$ & $<20$ & $<50$ & $<0.5$ \\
\hline Class 2: trace contaminated dredged material & $1-3$ & $50-150$ & $100-600$ & $35-150$ & $20-50$ & $50-100$ & $0.5-1.5$ \\
\hline Class 3: lightly contaminated dredged material & $3-5$ & $150-500$ & $600-1500$ & $150-300$ & $50-100$ & $100-400$ & $1.5-3.0$ \\
\hline Class 4: Lightly contaminated dredged material & $5-10$ & $500-1000$ & $1500-5000$ & $300-500$ & $100-500$ & $400-1000$ & $3.0-10$ \\
\hline Class 5: Highly contaminated dredged material & $>10$ & $>1000$ & $>5000$ & $>500$ & $>500$ & $>1000$ & $>10$ \\
\hline
\end{tabular}

Table 15. PIN index at different sampling station in Turag river.

\begin{tabular}{|c|c|c|c|c|c|c|c|c|c|c|c|c|}
\hline \multirow{2}{*}{ Location } & \multicolumn{2}{|c|}{$\mathrm{Pb}$} & \multicolumn{2}{|c|}{$\mathrm{Cd}$} & \multicolumn{2}{|c|}{$\mathrm{Cr}$} & \multicolumn{2}{|c|}{$\mathrm{Cu}$} & \multicolumn{2}{|c|}{$\mathrm{Zn}$} & \multirow{2}{*}{ PIN } & \multirow{2}{*}{ DR, 199} \\
\hline & $C_{i}$ & $W_{i}$ & $C_{i}$ & $W_{i}$ & $C_{i}$ & $W_{i}$ & $C_{i}$ & $W_{i}$ & $C_{i}$ & $W_{i}$ & & \\
\hline $\mathrm{T}-2$ & 34.40 & 1.00 & 0.10 & 1.00 & 33.50 & 1.00 & 46.30 & 2.00 & 113.80 & 2.00 & 6.38 & Clean \\
\hline $\mathrm{T}-3$ & 30.40 & 1.00 & 0.00 & 1.00 & 75.50 & 2.00 & 46.40 & 2.00 & 190.10 & 2.00 & 10.08 & Trace \\
\hline $\mathrm{T}-4$ & 28.30 & 1.00 & 0.40 & 1.00 & 32.00 & 1.00 & 50.00 & 2.00 & 94.60 & 1.00 & 5.41 & Clean \\
\hline $\mathrm{T}-5$ & 34.40 & 1.00 & 0.80 & 1.00 & 38.10 & 1.00 & 49.30 & 2.00 & 119.60 & 2.00 & 7.46 & Trace \\
\hline
\end{tabular}


Table 16. TCLP test result $(\mathrm{mg} / \mathrm{L})$ for the sediment sample of the Turag river [11].

\begin{tabular}{cccccc}
\hline Location & $\mathrm{Pb}$ & $\mathrm{Cd}$ & $\mathrm{Cr}$ & $\mathrm{Cu}$ & $\mathrm{Zn}$ \\
\hline $\mathrm{T}-1$ & 0.09 & 0.02 & 0.00 & 0.12 & 3.10 \\
$\mathrm{~T}-2$ & 0.08 & 0.01 & 0.02 & 0.18 & 2.33 \\
$\mathrm{~T}-3$ & 0.04 & 0.00 & 0.00 & 0.18 & 3.77 \\
$\mathrm{~T}-4$ & 0.01 & 0.00 & 0.00 & 0.13 & 0.61 \\
$\mathrm{~T}-5$ & 0.01 & 0.00 & 0.01 & 0.12 & 1.95 \\
$\mathrm{Mean}$ & 0.04 & 0.01 & 0.01 & 0.15 & 2.35 \\
$\mathrm{Max}$ & 0.09 & 0.02 & 0.02 & 0.18 & 3.77 \\
$\mathrm{Min}$ & 0.01 & 0.00 & 0.00 & 0.12 & 0.61 \\
$\mathrm{SD}$ & 0.04 & 0.01 & 0.01 & 0.03 & 1.20 \\
\hline
\end{tabular}

$94.60-190.10 \mathrm{mg} / \mathrm{kg}$ in the Turag river sediments. As per US EPA sediment quality guideline $\mathrm{Cd}$ belongs to not polluted. $\mathrm{Cr}, \mathrm{Cu}, \mathrm{Zn}$ belongs to moderately to highly polluted, $\mathrm{Pb} \& \mathrm{Cd}$ belongs to not polluted for Turag river. For all sites, concentrations of heavy metal in the leachate are not exceeded the permissible US EPA standard. That indicate regarding the readily toxicity pollution by heavy metal, Turag river sediment condition is not the severe state. Significant correlation found between the contaminants of $\mathrm{Cr}$ and $\mathrm{Zn}(\mathrm{r}=0.71), \mathrm{Pb}$ and $\mathrm{Cu}(\mathrm{r}=0.50), \mathrm{Zn}$ and $\mathrm{Cu}(\mathrm{r}=0.34)$ in Pearson's correlation for the heavy metals of Turag river. This concludes that those contaminants may have same or similar source input. Pollution load index (PLI) ranges from 1.35 - 3.03 in Turag rivers. According to geo-accumulation index, Turag river is unpolluted with $\mathrm{Cr} \& \mathrm{Zn}$. unpolluted to moderately polluted with $\mathrm{Pb}, \mathrm{Cd}$ and $\mathrm{Cu}$. According to PIN Index, all locations of Turag river sediments are clean to trace contaminated. Turag river has a low to moderate potential ecological risk due to heavy metal contamination. Degree of contamination of sediments of Turag river is low to moderate.

\section{REFERENCES}

[1] DoE, "Water Quality Data of Rivers Buriganga, Meghna, Balu, Shitalakhya, Jamuna (1991-2000)," Department of
Environment, Dhaka, 1997.

[2] O. Akoto, J. H. Ephraim and G. Darko, "Heavy Metal Pollution in Surface Soils in the Vicinity of Abundant Raiway Servicing Workshop in Kumasi, Ghana," International Journal of Environmental Research, Vol. 2, No. 4, 2008, pp. 359-364.

[3] H. Ghrefat and N. Yusuf, "Assessing Mn, Fe, Cu, Zn and Cd Pollution in Bottom Sediments of Wadi Al-Arab Dam, Jordan," Chemosphere, Vol. 65, No. 11, 2006, pp. 21142121. doi:10.1016/j.chemosphere.2006.06.043

[4] D. C. Thomilson, D. J. Wilson, C. R. Harris and D. W. Jeffrey, "Problem in Heavy Metals in Estuaries and the Formation of Pollution Index," Helgol. Wiss. Meeresunlter, Vol. 33, No. 1-4, 1980, pp. 566-575.

[5] P. K. Saha and M. D. Hossain, "Geochemical and Ecotoxical Approach for Evaluation of Heavy Metal Pollution in the Buriganga River Sediment," Proceedings of Bangladesh Geotechnical Conference, 2010.

[6] G. Muller, "Index of Geoaccumulation in Sediments of the Rhine River," Journal of Geology, Vol. 2, No. 3, 1979, pp. 108-118.

[7] J. M. Martin and M. Meybeck, "Elemental Mass Balance of Materials Carried by Major World Rivers," Marine Chemistry, Vol. 7, No. 3, 1979, pp. 173-206. doi:10.1016/0304-4203(79)90039-2

[8] J. Wilson, "Evaluation of Estuarine Quality Status at System Level with the Biological Quality Index and the Pollution Load Index (PLI)," Biology and Environment B, Vol. 103, 1987, pp. 47-59.

[9] L. Hakanson, "Ecological Risk Index for Aquatic Pollution Control, a Sedimentological Approach," Water Research, Vol. 14, No. 8, 1980, pp. 975-1001. doi:10.1016/0043-1354(80)90143-8

[10] P. K. Saha and M. D. Hossain, "Assessment of Heavy Metal Contamination and Sediment Quality in the Buriganga River, Bangladesh,” 2nd International Conference on Environmental Science and Technology, IPCBEE, Singapore, 26-28 February 2011.

[11] G. Muller, "The Heavy Metal Pollution of the Sediments of Neckars and Its Tributary: A stocktaking," Chem. Zeit., Vol. 105, 1981, pp. 157-164. 